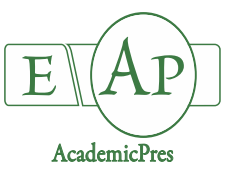

Yuhong G et al. (2021)

Notulae Botanicae Horti Agrobotanici Cluj-Napoca

Volume 49, Issue 4, Article number 12555

DOI:10.15835/nbha49412555

Review Article

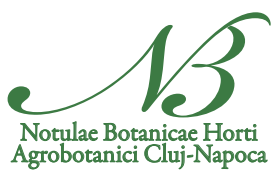

\title{
Role of conventional and molecular techniques in soybean yield and quality improvement: A critical review
}

\author{
Gai YUHONG ${ }^{1}$, Adnan RASHEED², Zhao ZHUO $^{3}$, \\ John J. GARDINER ${ }^{2}$, Muhammad ILYAS ${ }^{4}$, Muhammad AKRAM ${ }^{5}$, \\ Wang PIWU ${ }^{1}$, Syed F.A. GILLANI ${ }^{6}$, Maria BATOOL ${ }^{7}$, Wei JIAN ${ }^{2,8 *}$
}

\author{
1Jilin Agricultural University, College of Agronomy,China;gyh32101@163.com; peiwuw@163.com \\ ${ }_{2}^{2}$ Jilin Changfa Modern Agricultural Science and Technology Group Co., Ltd., China; adnanrasheed@jxau.edu.cn; \\ 148050459@qq.com (*corresponding author);johnjgardiner63@yahoo.com \\ 3jilin Normal University, College of Life Sciences, China; zhaozhuo8933@163.com \\ ${ }^{4}$ University College of Dera Murad Jamali Nasirabad (LUAWMS), Pakistan; muhammadilyas.ucdmj@luawms.edu.pk \\ ${ }^{5}$ Agronomic Research Institute, Faisalabad, Pakistan; akramkulachi2011@gmail.com \\ ${ }^{6}$ Gansu Agricultural University, College of Agronomy, Lanzhou 730070,China; faheemgillani33@gmail.com \\ ${ }^{7}$ Huazhong Agricultural University, College of Plant Science and Technology, Wuhan 430070, \\ China; maria.batool@webmail.hzau.edu.cn \\ ${ }^{8}$ Changchun Normal University, College of Life Sciences, China; 148050459@qq.com
}

\begin{abstract}
The soybean is one of the most significant legume crops around the globe and serves as a source of dietary components for humans and animals. It has a higher percentage of protein compared to any other crop. Soybean yield and quality have been affected by many environmental factors. The genetic mechanism of yield and quality is still not clearly understood. Hence there is still a need to investigate the major potent factors to shed light on the mechanism behind yield and quality traits in soybean. Recently, a lot of significant work, including novel QTL, genes, and CRISPR-based genome editing in soybeans, has been done, which opened new doors of hope. The current review has presented detailed work done previously. We have also discussed the role of different breeding techniques in the conventional way of soybean improvement. The genetic factors regulating yield, quality, and disease resistance could be further cloned and transferred into elite cultivars to attain higher output in the current situation of changing environment. The integrated use of several techniques, like CRISPR/Cas9, next-generation sequencing, omics approaches, would be a fruitful way to improve soybean yield and quality. Besides this, hybridization, mass selection, pure line selection, backcross breeding, and pedigree selection should be adopted to develop novel soybean cultivars. This review concluded that soybean yield and quality improvement could be enhanced by exploring its genetic mechanism using several molecular and conventional methods.
\end{abstract}

Keywords: conventional methods; molecular techniques; soybean; yield; quality

Abbreviations: QTL: Quantitative traits loci; Soy: Soybean; Chr: Chromosomes; Gen: Genomics

Received: 02 Nov 2021. Received in revised form: 05 Dec 2021. Accepted: 08 Dec 2021. Published online: 20 Dec 2021.

From Volume 49, Issue 1, 2021, Notulae Botanicae Horti Agrobotanici Cluj-Napoca journal uses article numbers in place of the traditional method of continuous pagination through the volume. The journal will continue to appear quarterly, as before, with four annual numbers. 


\section{Introduction}

The soybean (Glycine max) is one of the important and oldest legumes known and consumed by human beings. This crop has a higher percentage of oil, protein, and other valuable products, and its production is increasing every year because of increasing demand day by day (Contini et al., 2013; Bao et al., 2019). The soybean contributes to $69 \%$ of oil and $30 \%$ of the protein consumed by livestock (Van and McHale, 2017). Genetic and environmental factors that impact the polygenic traits are difficult to improve by conventional breeding $(\mathrm{Li}, 2006)$. The huge genetic diversity among the lines makes it easy to differentiate the lines in the field trails. The yield is an ultimate goal of any breeding program in soybean, and it is generally associated with seed size and plant architecture. In general terms, plants with unified architecture are expected to have higher yields than plants with contrasting traits. To overcome this difficulty, breeders have selected relatively simple traits to enhance yield, which is least influenced by external factors and controlled by small genetic loci (Hartung et al., 1981).

Hence, understanding the genetic basis of small traits, their characterization, and their role in improving the yield and quality of soybean is helpful to speed up the breeding programs using different breeding methods (Cober and Morrison, 2010). In China, soybean production has decreased over the past few years due to the low yield trend during the last 50 years (Liu et al., 2018). The country imports $80 \%$ of the soybean for domestic use, and hence it's become essential to make the country self-sufficient by increasing its yield by developing high-yielding varieties (Liu et al., 2018; Sharmin et al., 2020). The US-China trade war has negatively affected China's soybeans yield and increased costs. This change in international soybean trade would lead to the noticeable growth of global environmental costs in the short term due to surplus soybeans in the US and the enhanced food transportation distance (He et al., 2019). The breeders have successfully targeted the genes contributing to high yields in soybean (Karikari et al., 2019).

China is now the 4th main soybean producer. China's soybeans are grown over a large latitudinal variety and in varied ecological environments and cropping schemes that spread from the frigid areas of Northern China to the tropical expanses of Southern China (Wang et al., 2007). China has the highest genetic diversity of soybean germplasms (Liu et al., 2017b). Contemporary soybean breeding started in China in 1913 (Wang et al., 2007), about 30 years earlier than North America (Rincker et al., 2014). The first formally unrestricted soybean cultivar, 'Huangbaozhu', was described in 1923 (Zhou et al., 2000). In recent years, conventional breeding techniques have significantly contributed to the development of high-yielding soybean cultivars (Ahmar et al., 2020). However, the traditional method is not adequate to increase the yield to feed the rapidly growing population (Ashraf et al., 2010; Bhat et al., 2016). These methods applied to select phenotypic traits are not sufficient to meet the criteria of global food security (Mir et al., 2019). Advanced genomics and phonemics techniques give excellent opportunities to adopt precision breeding at a higher level (Mir et al., 2019). For instance, the genomic assisted selection method allows understanding of major traits, but it needs a complete molecular understanding (Chaudhary et al., 2015; Steiner et al., 2019). Soybean yield is polygenic trait and controlled by many genes. The improvement of multigene traits is often challenging and not fruitful. There are many traits which contribute to yield improvement, and hence improvement of soybean yields via conventional breeding is very lengthy and costly process. Soybean quality is a monogenic trait which means that this trait is regulated by a single gene and its improvement is not challenged by environmental factors (Dong et al., 2004)

Genomic assisted breeding is emerging as a potent tool in large-scale breeding plans (Hickey et al., 2017). It unlocks new windows to select lines in early generations (Yao et al., 2018). These techniques enable the early selection of lines, reduce the field tests, and enhance reuse in breeding programs as parental material. Using this way, we can select lines earlier with less error. This exercise was only promising after developing high-density marker pieces that are presently accessible for numerous crops. Markers are extensively used to assume relations at the QTL level, assessing whether the LD among markers and QTL is practically high (Habier et al., 2007). A list of high-yielding genotypes is shown in Table 1 . This review sheds light on recent insights about soybean yield and quality improvement. The study discusses the potent genetic factors regulating soybean yield and 
quality improvement and highlights future directions. The reasons for the low soybean yield in China are shown in Figure 1.

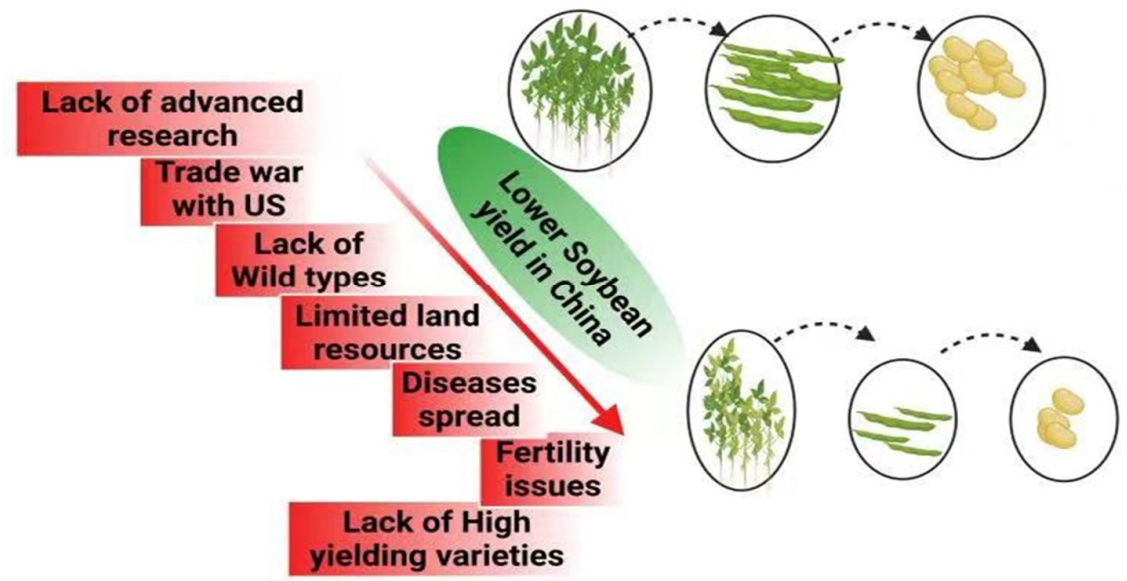

Figure 1. The key reasons for low soybean yield in China

Table 1. List of some high yielding soybean cultivars

\begin{tabular}{|l|c|c|}
\hline \multicolumn{1}{|c|}{ Sr. No } & Soybean genotypes & Origin \\
\hline 1 & 'Huangbaozhu' & China \\
\hline 2 & 'China-1' & China \\
\hline 3 & 'Australia' & Australia \\
\hline 4 & 'Bhat' & India \\
\hline 5 & 'Kala soybean' & China \\
\hline 5 & 'Henong 71' & China \\
\hline 6 & 'Jinong 74' & China \\
\hline 7 & 'Jinong 75' & China \\
\hline 8 & 'Shidadou 1' & China \\
\hline 9 & 'Xindadou 1' & China \\
\hline 10 & 'Suinong 1' & \\
\hline
\end{tabular}

\section{Soybean domestication from wild to cultivated}

Many genetic links occurred during the domestication and diversification of soybeans, particularly in Asian landraces (Hyten et al., 2006). Accidently half of the genetic diversity (Zhou et al., 2015) and about 81\% of alleles (Hyten et al., 2006) were lost during the domestication of Glycine soja landraces. In the North American breeding pool, only 19 landraces have contributed to the genes of desired traits (Gizlice et al., 1996). It is stated that the modern-day soybean originated from a wild-type species in east Asia about 6000-9000 years ago (Carter et al., 2004; Kim et al., 2012). The origin of the soybean is still a mystery because of the lack of molecular studies and other evidence. Hence, modern research on molecular aspects and whole-genome sequencing have shed light on this valuable crop's origin. The historical evidence suggested that the soybean originated from northeastern China in 2510BP, which led to the agricultural revolution (Ho, 1975). Most of the landraces diversity was discovered along the Yellow River (Dong et al., 2004; Li et al., 2010). Placed around this area, plenty of archeological, soybean specimens (Zhijun, 2004; Lee et al., 2011) around the Yellow River bowl as a main nominee for the source of soybean domestication. Otherwise, the Yangtze basin has also been recommended as a birth place of the soybean based on phylogenetic and clustering analyses with microsatellites and nucleotide variety (Guo et al., 2010). 
Furthermore, archeological histories display larger soybean seeds in Japan and Korea related to seeds discovered in the Yellow River basin in China throughout the era 5000-3000BP (Lee et al., 2011). Specifically, soybean seed models from Japan were leading throughout this period. These results, composed of the long deviation time among Glycine max and Glycine soja as defined before, designate that there may have been multiple works to domesticate wild soybeans. Certainly, the existence of wild soybeans in grain imitations on ceramic was seen as early as 7000-5000BP in Japan (Obata and Manabe, 2011). The latest evidence show that the domestication process had improved several soybean traits. The photosynthesis, nitrogen content and stomatal conductance have been improved by using the domestication process in wild soybean lines (Togashi and Oikawa, 2021). Likewise, the GmOLEOI gene significantly improved the soybean oil quantity during domestication in the field (Zhang et al., 2019).

\section{Conventional breeding methods to improve soybean yield and quality}

\section{Ways towards a revolution in soybean yield}

Yield is a multigene trait governed by many genetic factors (Rasheed et al., 2020a, 2020b; Rasheed et al., 2020; Rasheed et al., 2021b; Rasheed et al., 2021c). The yield is influenced by the number of seeds, seed size, height, branch number, number of pods, and seeds per pod (EL Toum et al., 2020). The angle and the petiole length also distress the final harvest. For maximum planting density, a suitable breeding design is the first criteria to be considered (EL Toum et al., 2020). An additional breeding method is important to enhance PH and node number. Plants with tall heights are often lodged, while small plants are resistant to lodging (Panthee et al., 2007). Other possible optimization characteristics which may affect higher yields include the number of seeds per pod, seed size, and petiole length. Theoretically, the number of seeds per pod, as well as the size of the seed, can increase the final harvest (Rasheed et al., 2017; Rasheed et al., 2018; Rasheed et al., 2019), although short petiole and enhanced leaf size will be favorable to thick planting and photosynthetic effectiveness. Particularly, numerous environmental factors containing climate situation, synthetic features, and even planting date can also significantly influence final soybean yield (Robinson et al., 2009). Earlier findings also showed that adaptive changes could critically donate to the growth and production of soybean in the planting area (Yue et al., 2017).

Consequently, breeding the cultivars with developed environmental alterations is also significant for high soybean production (Liu et al., 2020b). Several breeding techniques are hybridization, mass selection, recurrent selection, pure line selection, speed breeding, backcross methods, and pedigree method; however, hybridization is the most successful breeding method used in crops. Soybean seed size and yield were improved using the mass selection breeding method (Cober and Voldeng, 2008). In the same way, Lee et al. (2015) used the pedigree selection method to improve soybean cultivars. The cultivars showed good yield and quality. The pedigree method would help the breeder to improve the soybean further. The main breeding objectives of soybeans are shown in Figure 2.

\section{Hybridization breeding}

In addition to the expansion of Green Revolution lines, other methods have also added greatly to crop yield rise during the last several periods. A good example is heterotic breeding, also called hybrid breeding, which means that hybrid vigor shows a higher yield than parental genotypes (Liu et al., 2020a). For instance, hybrid breeding has increased maize yield by $15 \%$ compared to inbreeding (Duvick, 2001). Initially, it was impossible to develop hybrid genotypes in self-pollinated crops, but later on, the discovery of sterile male lines made it possible to develop hybrids in rice. As a result of these efforts, hybrid cultivars have shown a 10-20\% increase in yield compared to conventional varieties (Cheng et al., 2007), making it a significant development in current rice breeding programs. Newly, great development in wheat heterotic breeding has also been completed, and the hybrid genotypes with beneficial yield have been gained and sold in EU countries (Gupta 
et al., 2019). The hybrid breeding program has been extensively used in numerous other crops, such as soybean and sorghum (Seiler et al., 2017).

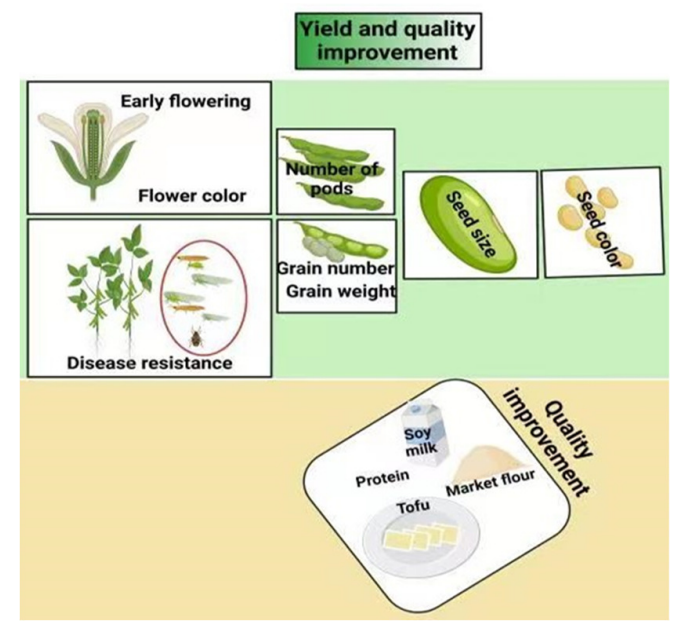

Figure 2. The main breeding targets in soybean are yield, quality improvement and diseases resistance

It has been stated that the development of hybrid vigor in soybean does occur and that hybrid soybean $\mathrm{F}_{1}$ lines showed a $20 \%$ yield rise over that of their extraordinary parents (Palmer et al., 2001). The soybean is an autogamous crop with a small percentage of natural cross-pollination, and pollen transmission is the most difficult way soybean breeders adopt. But we hope that the answer for effective pollen transmission may open the window for soybean hybridization in the coming time, which would be a noteworthy development toward the rise of soybean yield (Liu et al., 2020b). 'MACS-1188' and 'Pant Soybean-19' are the cultivars developed by the hybridization method. The modified hybridization techniques would lead to more efficient and highyielding cultivars in soybean crops. The conventional way to breed soybean cultivars is shown in Figure 3.

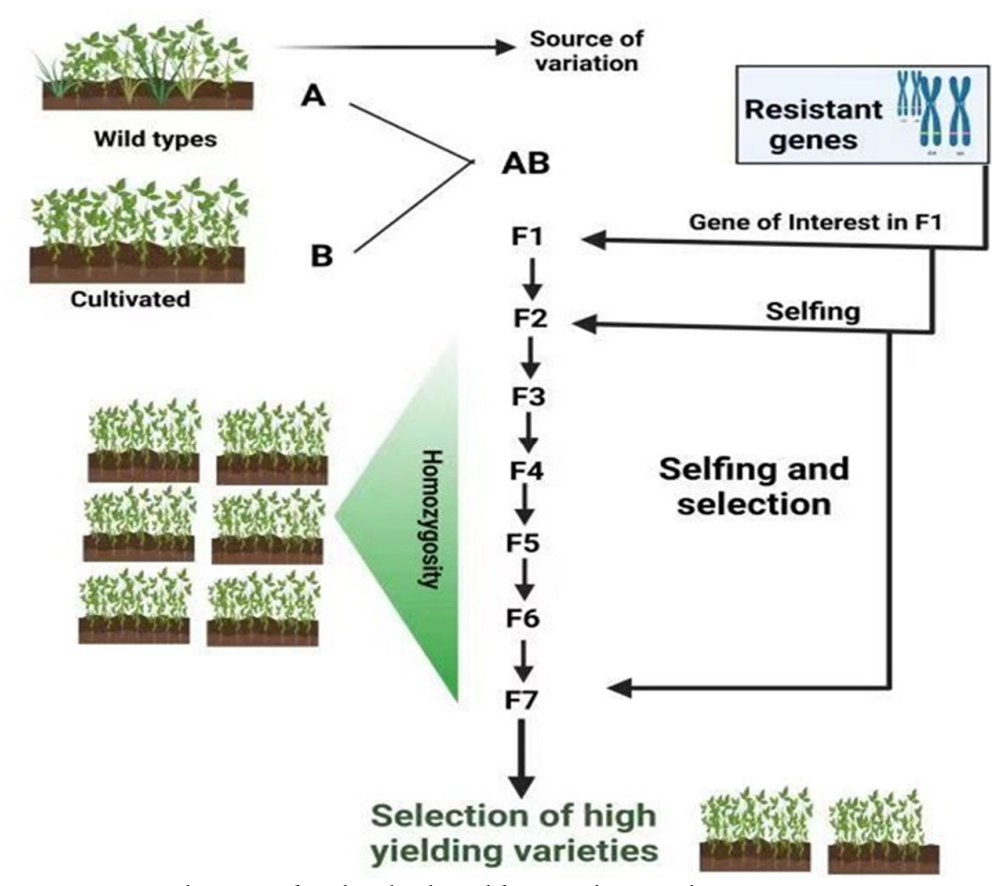

Figure 3. The conventional way to develop high yielding soybean cultivars 


\section{Use of fertilizers}

To attain a significant point in soybean yield and quality, the use of highly effective fertilizers is one of the main agronomic approaches (Onyenali et al., 2020). A field experiment was conducted to examine the effect of organic fertilizers on soybean yield and quality. Organic fertilizers significantly improved the yield and quality of soybeans compared to the control one (Onyenali et al., 2020). It is significant to recognize better the effects of the use of long-period fertilizer on crop yield, soil features and nitrogen $(\mathrm{N})$ use efficacy in a replacement crop farming system under the circumstances of recurrent soil disruption. Hua et al. (2020) studied the effects of manure application on the yield of 40 years of soybean and maize crop rotation. Their outcomes presented that long period use of organic fertilizer could efficiently increase $\mathrm{N}$ use efficiency by enhancing soil organic manure and refining soil fruitfulness, thus leading to a rise in crop yield. Likewise, the application of $\mathrm{N}$ was added in the soil to examine its effects on soybean grain yield. $\mathrm{N}$ was applied at a concentration of $75 \mathrm{~kg} \mathrm{ha}^{-1}$ (Table 2). A noteworthy association was found between photosynthesis and grains yield at developmental stages. This study directed that the use of $\mathrm{N}$ is essential to increase soybean harvest across the Sanjiang River Plain in PR. China (Gai et al., 2017). The use of nitrogen fertilizer to increase soybean was reviewed by Ohyama et al. (2016), and they have concluded that large application of $\mathrm{N}$ with a low release rate encouraged the growth and seed yield as well as the quality of soybeans without discouraging the nitrogen fixation process (Ohyama et al., 2017).

The use of fertilizer not only affects soybean yield but also influences its quality. Late season nitrogen was applied to the soybean field to investigate its effects on yield and protein concentration. $\mathrm{N}$ at the rate of $202 \mathrm{~kg} \mathrm{ha}^{-1}$ was applied to the field, and results showed that late-season $\mathrm{N}$ could significantly improve the soybean yield and quality. However, they have stated that a new study is essential to examine maintainable management approaches that increase $\mathrm{N}$ accessibility to late-season soybean (Chiluwal et al., 2021). The yield and quality of soybeans were affected by integrated fertilizer management and application of zeolite. Amiri et al. (2021) showed that applying zeolite $12 \mathrm{Mg} \mathrm{ha}^{-1}$ significantly improved the soybean yield and quality. The research proves that altering soil with these ordinary fertilizer's composts could be a capable plan to increase soybean yield and quality. The use of sulfur as a fertilizer is highly recommended for soybean production. The impact of $S$ application $\left(168 \mathrm{~kg} \mathrm{~S} \mathrm{ha}^{-1}\right)$ on soybean yield and crude protein was studied. Adding $S$ did not alter the $\mathrm{CP}$ of soy seed; however, the $S$ contents were slightly higher (Letham et al., 2021).

Zinc fertilizer also plays a major role in soybean yield and quality. In an experiment, zinc at the concentration of $4500 \mathrm{~g} \mathrm{ha}^{-1}$ was added to the soybean field, and significant effects were observed on soybean yield and quality (Aytaç et al., 2007) (Table 2). Limestone and copper were applied to the soybean field, and their effects were studied on soybean quality, soil fertility, and nutritional status. Limestone at the concentration of $5.0 \mathrm{Mg} \mathrm{ha}^{-1}$ and $\mathrm{Cu}$ at the concentration of $16 \mathrm{mg} \mathrm{kg}^{-1}$ were applied. They have significantly increased the number of grains per pod (Santos et al., 2020). Biochar at a concentration of $5.0 \mathrm{t} \mathrm{ha}^{-1}$ was added to the soil. Its effects on soybean yield and quality were studied. Results showed that using this treatment can reduce the use of ammonium sulfate and increase the soybean yield (Alam et al., 2020). These findings showed that fertilizer application is a vital step towards higher soybean yield achievement. The integrated use of fertilizers would be a promising approach for higher yield in soybean (Bhat et al., 2016). However, further studies are required for a more in-depth analysis of fertilizer role in soybean yield and quality improvement. 
Table 2. Significant effects of fertilizers on soybean yield and quality improvement

\begin{tabular}{|c|c|c|c|c|}
\hline Crop & Fertilizer & Concentration & Trait improvement & References \\
\hline \multirow{5}{*}{ Soybean } & Zinc & $4500 \mathrm{~g} \mathrm{ha}^{-1}$ & Yield and quality & (Aytaç et al., 2007) \\
\cline { 2 - 5 } & $\mathrm{N}$ & $75 \mathrm{~kg} \mathrm{ha}^{-1}$ & Grain yield & (Gai et al., 2017) \\
\cline { 2 - 5 } & Potassium $(\mathrm{K})$ & $\mathrm{K} 150 \mathrm{~kg} \mathrm{ha}^{-1}$ & Yield & $\begin{array}{c}\text { (Shahkoomahally and } \\
\text { Shahkoomahally, 2017) }\end{array}$ \\
\cline { 2 - 5 } & Nitrogen & $668.5 \mathrm{~kg} \mathrm{ha}^{-1}$ & Yield & (Hua et al., 2020) \\
\cline { 2 - 5 } & Limestone & $5.0 \mathrm{Mg} \mathrm{ha}^{-1}$ & Grains number per pod & (Santos et al., 2020) \\
\cline { 2 - 5 } & Copper & $16 \mathrm{mg} \mathrm{kg}^{-1}$ & Grains number per pod & (Santos et al., 2020) \\
\cline { 2 - 5 } & Biochar & $5.0 \mathrm{t} \mathrm{ha}^{-1}$ & Yield & (Alam et al., 2020) \\
\cline { 2 - 5 } & Nitrogen $(\mathrm{N})$ & $202 \mathrm{~kg} \mathrm{ha}^{-1}$ & Yield and protein & (Chiluwal et al., 2021) \\
\cline { 2 - 5 } & Zeolite & $12 \mathrm{Mg} \mathrm{ha}^{-1}$ & Yield and quality & (Amiri et al., 2021) \\
\cline { 2 - 5 } & Sulfur & $168 \mathrm{~kg} \mathrm{Sha}^{-1}$ & Yield and crude protein & (Letham et al., 2021) \\
\cline { 2 - 5 } & & &
\end{tabular}

\section{Early sowing}

The sowing date is particularly important in soybean yield and quality because it affects the formation of vegetative and reproductive parts (Nico et al., 2019) and, ultimately, final biomass. The early planting of soybean cultivars showed improved growth and quality (Divito et al., 2016). Earlier research studies showed that sowing date is a serious management choice that disturbs soybean development, growth features and, grain yield (Zhang et al., 2010b). Until the end of the last century, little research was published on soybeans due to a lack of proper knowledge and germplasm. However, research work on soy crops was significantly improved in all aspects at land grants associations institutes (Khan et al., 2020). Research showed that the soybean crop planted early in May yielded more pods than the late-planted crop (Lueschen et al., 1992). Different types of cultivars have different yield trends. The determinate type of soy cultivars exhibited higher yield when planted in May than indeterminate types sown later (Robinson et al., 2009).

Another research study showed that sowing in April showed a higher yield than cultivars planted in May (Robinson et al., 2009). Likewise, soybean genotypes planted in April or early May recorded higher yield percentage. The grains yield data was collected for early sowed genotypes. Analysis showed that early sowing genotypes have more grains than late sowing genotypes (Egli and Cornelius, 2009). The studies reported the subsequent increase in seed yield from a given area. Lakpale and Tripathi (2012) showed that growth factors, yield features, and grain yield of soybean genotypes were recorded maximum, and soybean oil content was considerably changed by managing soybean genotypes sowing date and time. Sowing in early July yielded $72 \%$ more grains yield than that of delayed sowing.

Similarly, the early sowing date improved the grain protein of soybean by $5 \%$ compared to late sowing (EL Toum et al., 2020). Jarecki and Bobrecka-Jamro (2021) assessed the influence of sowing dates on soybean yield and quality by growing soybeans in dissimilar sowing intervals. They have determined that early sowing time increased the pod's number per plant and 1000 seed weight. All of these above findings showed that soybean yield and quality can be improved significantly by adjusting the sowing date.

\section{Use of hormones}

Hormones like gibberellins, cytokinin, and auxins promote the plant growth and yield and are important plant growth-promoting factors. Phytohormones can cause physiological and morphological modifications that rely on their application rate, tissue sensitivity, and crop species. Plant growth hormones can encourage, hinder, or change plants' physiological procedures depending on the application rate (Santner and Estelle, 2009). Llanes et al. (2019) studied the effect of different plant hormones on the growth and yield of soybeans. The foliar application of gibberellic acid significantly improved the yield of soybeans. The effect of auxin and cytokinin on pod set in soybean was studied, and results indicated that auxin had positive effects on soybeans pod setting rate (Nonokawa et al., 2007). The CK has a key role in facilitating the nodule development in soybean. The treatment of seeds with cytokinin increased yield and nitrogen usage in soil 
(Kempster et al., 2021). The plant growth regulator and its effect on soybean yield were studied by Klumpp (2018). The application of growth regulator auxin had positive effects on soybean yield. This yield benefit was due to soybean plants yielding maximum nodes to develop extra seeds and pods, leading to a higher yield.

The use of hormones or growth regulators during the soybean pod initiation stage exhibited a weighty effect on PH, branches per plant and seed yield. Findings showed that soybean seed yield was recorded highest by spraying 2,3,5-triiodobenzoic acid at a concentration of 50ppm in an area of $21.24 \mathrm{q} /$ ha (Solanke et al., 2018). Salicylic acid (SA) is an endogenous signaling hormone. It has numerous roles, particularly in sprouting and growth, interference with root immersion, condensed leaf abscission and transpiration (Ashraf et al., 2010; Hayat et al., 2010). Abscisic acid and its role in soybean yield were studied in an experiment. The ABA hormone at a concentration of $(300 \mathrm{mg} / \mathrm{L})$ was used as a foliar spray at the V7 and R2 phonological phases, whereas GA3 (300 mg/L) was used at R2 and seven days later. Results showed that plants treated with ABA have more roots and shoots and ultimately a higher yield (Travaglia et al., 2009). The use of SA also considerably improved the root dry weight parameter. SA also increased soybean seed dry weight (Khan et al., 2003). Pod shattering rate is one of the main determinants of soybean yield. Using two different genotypes of the soybean crop, researchers Taniguchi et al. (2018) studied the association between plant growth facilitated by gibberellin and pod setting ratio. After flowering, the plant growth rate was meaningfully improved in Fukuyutaka and lower in the Kariyutaka genotype. Hence, it is proven that soybean yield and quality can be increased by using plant growth hormones. More studies are needed to understand the critical role of these growth regulators behind higher-yield and good-quality soybeans.

\section{Molecular tools to enhance soybean yield and quality}

\section{QTL for soybean yield improvement}

Enhancement of soybean yield plays a significant role in meeting the high demand for protein in China and other countries. Different studies were conducted to improve the soybean yield and quality, and many significant QTL were identified for these yield and quality traits (Prince et al., 2020). The soybean yield is the ultimate product of any breeding program, and identification of genomic regions for this trait can increase yield by MAS selection. Zhao et al. (2021) used 175 recombinant lines (RILs) to estimate yield and quality traits. They have conducted field trials for consecutive years. The QTL $q G Y 6.2$ identified for yield was marked as a major QTL and significantly contributed towards yield improvement, as shown in Table 3. In another experiment, the RIL population was evaluated for QTL mapping, and 13 yield-related QTL were identified. Some of the genomic areas displayed pleiotropic influences on yield characters. They further recognized candidate genes for these areas. These results laid the foundation for developing high-yielding soybean cultivars with outstanding characters (Su et al., 2019).

Likewise, two mapping populations, SD02- $911 \times$ SD00-1501 and SD02- 4-59 × A02-381100, were phenotype for QTL mapping and 12 QTL for seed yield were identified on different chromosomes. Further analysis evidenced that these QTL were leading regions towards higher yield in soybeans (Wang et al., 2014). Zhang et al. (2010a) worked on a RIL population from 'Nannong 94-156' and 'Bogao' and detected two QTL $q p n 11$ and $q p n 20$, which regulated the number of pods per plant which ultimately led to the higher yield in soybeans. A large number of QTL, $q$ PH13a, $q N N 19$ a, $P H 19 b-2$ related to plant height and pod number per plant were identified in a study using RIL population, signifying that plant height and pod number are important traits for a higher soybean yield (Liu et al., 2017a). 100-seed weight (HSW) is one of the most powerful yield-related traits studied by researchers. Qi et al. (2020) conducted GWAS for HSW of soybean cultivars by using $144 \mathrm{FW}$-RILs populations based on data collected from 20 diverse environments. The study identified 118 QTL out of them 2 QTL, $q H S W 2$ and $q H S W 3$ for HSW were major regions and identified potential alleles behind the expression of these QTL. A QTL mapping was done based on 944 RILs population resulted from a five-parent half-diallel crossing plan. 
They recognized five to eight QTL for each of the four key agronomic characters, and some showed a substantial amount of genotypic modification. Two main QTL, $q S Y 1$ and $q S Y 2$, were significant QTL controlling seed yield in soybean cultivars (Zhu et al., 2021). These findings contributed to understanding the gene network controlling important yield-related traits in soybeans. Seed weight is a significant soybean yield constituent and influences the quality of soya foods. 112 RILs were used to map the QTL linked to soybean seed weight contributing to the yield. The QTL, $q S W 1$ and $q S W 20$ were mapped on chromosomes 1 and 20, highlighting the genetic mechanism behind the yield increment in soybeans (Wu et al., 2018). Yield-related components also play a key role in yield enhancement, and plant breeders identified QTL for these traits. Li et al. (2020) used 208 CSSL populations and identified 24 QTL for plant height located on different chromosomes. $q P H-m-1$ and $q P H-o-2$ were detected for $\mathrm{PH}$, and they strongly influence the soybean yield.

$\mathrm{PH}$ is a significant feature in soybean, as taller plants may have a greater yield (Xue et al., 2019). Thirtysix regions governing $\mathrm{PH}$ were identified at numerous developmental phases and showed uneven effects (Xue et al., 2019). 1000 seed weight is a key contributor to soybean yield, and many previous studies have identified QTL for this trait. Previously a QTL, swHCA2-1 for 1000-seed weight was identified by Han et al. (2012), $q S_{W} 17-1$ by Kato et al. (2014) and $q S W T_{-} 13 \_1$ by Yan et al. (2014) as shown in Table 3. The two major genes, CHS7 and CHSS involved in isoflavonoid synthesis in soybean (Yi et al., 2010). Likewise, FKKI and G1 regulate soybean photoperiod ( $\mathrm{Li}$ et al., 2013). Hence, it is mandatory to identify the putative genomic regions and transfer them into candidate cultivars via MAS to increase soybean yield. More studies are required to understand the soybean genetic architecture behind the high-yielding attitude.

Table 3. Significant QTL in soybean associated with yield and yield-related traits

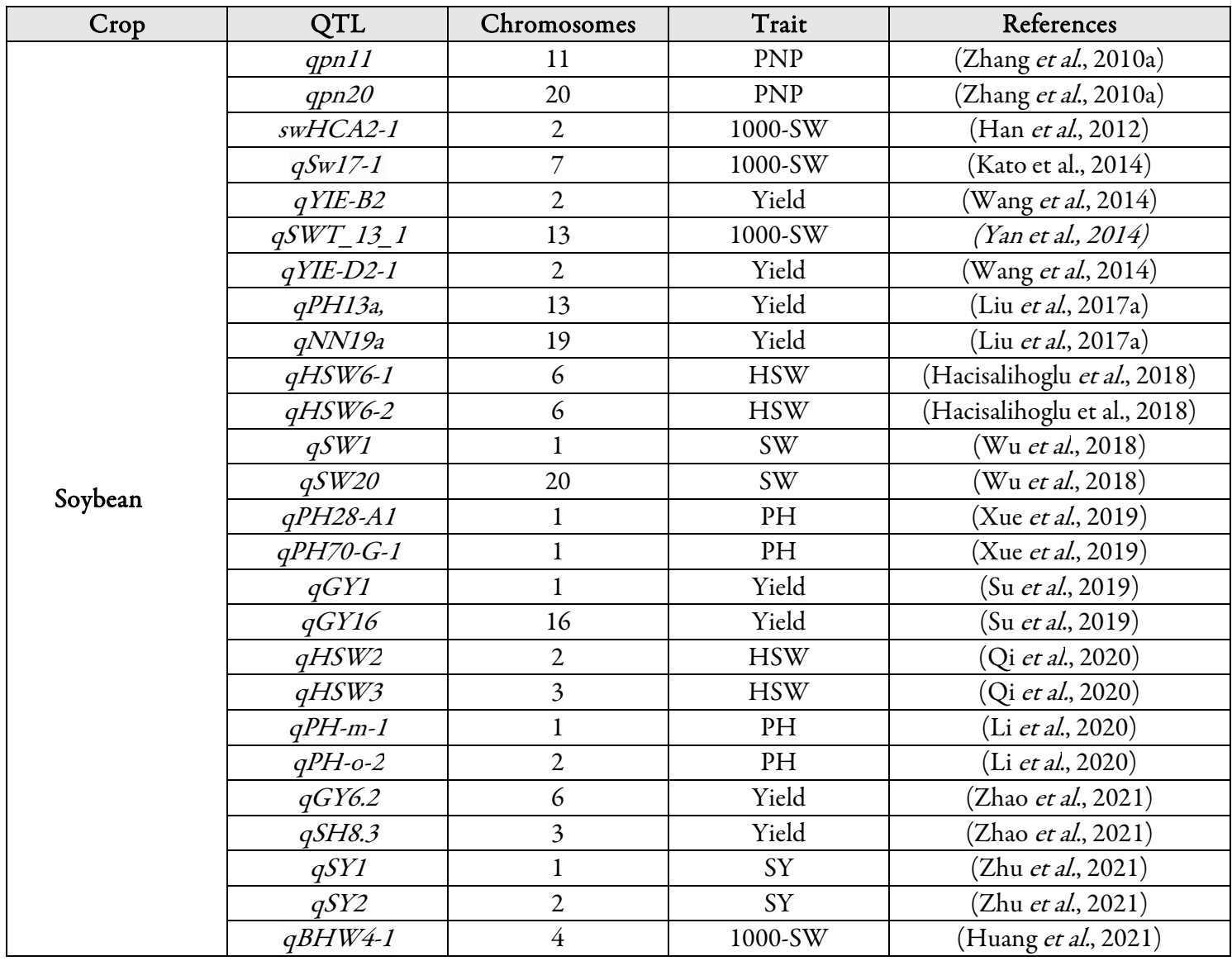




\section{QTL for soybean quality improvement}

Being an important oil crop globally, soybean yield and quality improvement are always key objectives for plant breeders. In an experiment, a total of 20 QTL governing linoleic acid, oil and palmitic acid were identified, varying in their expression (Silva et al., 2021). Enhancing the content of soybean storage protein while increasing the ratio of glycinin to $\beta$-conglycinin is of great importance for soybean breeding plans and soybean food products. In an experiment, $35 \mathrm{QTL}$ and five major significant genomic areas were detected using the RIL population. The two significant QTL, $q 11 S-6-2$ and $q S G C-6-2$ improved the glycinin and conglycinin contents in soybean (Ma et al., 2016). Oil and protein contents were significantly improved to attain better soy quality. Two major QTL, $q O C 1, I$ and $q P C 2$ controlling oil, and protein contents were detected on chromosomes 1 and 2 (Liang et al., 2010).

Likewise, Zhang et al. (2018) used 313 diverse soybean accessions and genotyping was done with highquality SNP and identified QTL, $q P A 5$ and $q O C 5$ controlling palmitic acid and oil content in soybean accessions. These findings suggested that the genetic mechanism of soybeans could be understood more clearly by using high-resolution mapping populations. To improve the fatty acid contents in soybeans, a study was conducted and QTL mapping was done to identify the QTL regulating the fatty acid contents. In total, 18 QTL were mapped on different chromosomes explaining varying ranges of phenotypic variance. The study suggested that these major and minor QTL should be used to improve fatty acid contents in soybeans (Zheng et al., 2006). Zhang et al. (2021) conducted a genome-wide association study to identify the QTL for protein contents and water-soluble proteins. A total of 211 diverse genotypes were used for this study. The QTL, $q P C$ 15-1 and WSPC-8-1 were potent QTL, which enhanced the required quantity of proteins. The best way to improve soy quality is to map the major regions across various populations. Wang et al. (2020b) identified the 14 new QTL, $q H C 8$, which improved the hexanal contents in soybean. The first GAWS study identified many novel QTL and many genes behind these regions. An experiment detected the QTL controlling the soymilk off-flavor on many chromosomes. The QTL, $q O C 18$ identified on chromosome 18, was a highly valuable region because it enhanced the soy 1-octen-3-ol content, which improved the soybean milk flavor (Xia et al., 2019).

Seed size and shape also contribute to soybean quality features, as better size and shape would attract the consumers to buy more products. Many studies have been conducted to identify the hotspot regions for soybean seed size and seed shape traits. In one attempt, RILs were evaluated, and QTL mapping was conducted to identify the QTL for these significant traits. Two QTL, $q S L-13-3$ and $q S L-13-4$ (Table 4), were detected on chromosome 13, governing the seed size and shape in soybean. Hence, overall, these studies showed that soybean yield and quality improvement are significant targets for any plant breeding program. Many studies have been done on this, but major genes have not been cloned up to now. There is a current need to conduct studies using diverse populations to kick off the significant variation for attaining targeted results. The use of ideal and high-resolution mapping populations would yield important results for soybean improvement. The global food supply chain is presented in Figure 4. 


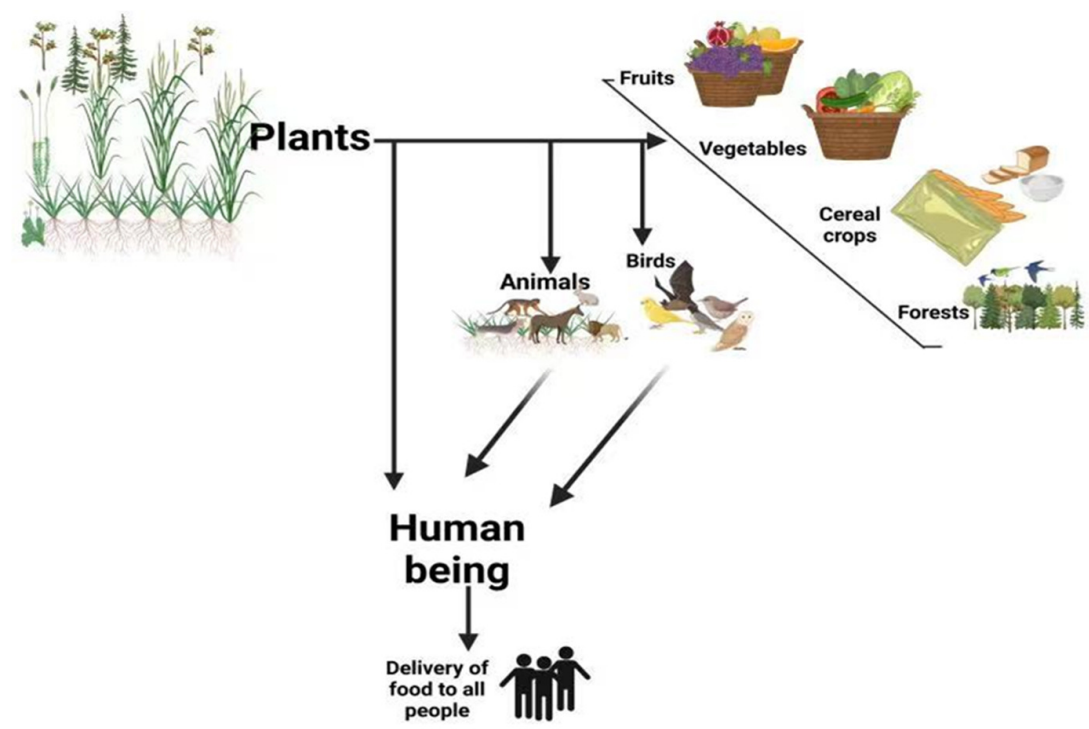

Figure 4. The global food supply chain represents the flow of food from the source to the final consumer in the ecosystem

Table 4. Quality traits QTL in soybean using different mapping populations

\begin{tabular}{|c|c|c|c|c|}
\hline Crop & QTL & Chromosomes & Trait & References \\
\hline \multirow{14}{*}{ Soybean } & $q O C 1$ & 1 & Oil content & (Liang et al., 2010) \\
\hline & $q P C 2$ & 2 & Protein content & (Liang et al., 2010) \\
\hline & $q 11 S-6-2$ & 6 & Conglycinin & (Ma et al., 2016) \\
\hline & $q S G C-6-2$ & 6 & Glycinin content & (Ma et al., 2016) \\
\hline & $q P A 5$ & 5 & Palmitic acid & (Zhang et al., 2018) \\
\hline & $q O C 5$ & 5 & Oil content & (Zhang et al., 2018) \\
\hline & $q O C 18$ & 18 & Soymilk off-flavor & (Xia et al., 2019) \\
\hline & $q S L-13-3$ & 13 & Seed size & (Hina et al., 2020) \\
\hline & $q S L-13-4$ & 13 & Seed size & (Hina et al., 2020) \\
\hline & $q H C 8$ & 8 & Hexanal contents & (Wang et al., 2020b) \\
\hline & qPal-02 & 2 & Oil content & (Silva et al., 2021) \\
\hline & qOle-02 & 2 & Oil content & (Silva et al., 2021) \\
\hline & $q P C-15-1$ & 15 & Protein & (Zhang et al., 2021) \\
\hline & WSPC- $8-1$ & 8 & Water-soluble proteins & (Zhang et al., 2021) \\
\hline
\end{tabular}

\section{Role of CRISPR/Cas9 in soybean genetic improvement}

\section{CRISPR/Cas9 based targeted genome editing in soybean}

After completing soybean genome sequencing, the major challenge faced by the researchers was to identify the role of thousands of soy genes individually (Bai et al., 2020). The transgenic technique for a comprehensive understanding of the soybean genomic model is valuable, but it has several limitations in practical use. During the last few years, the transformation of soybeans using Agrobacterium has been widely increased because of its simplicity, low cost and fewer rearrangement errors.

In 2011, a genome-editing tool generated heritable mutants in two homologous genes DCL4 and $D C L 4 b$ (Curtin et al., 2011). TALENs tool was first applied in soybeans to alter two fatty acid genes FAD2$1 A$ and $F A D 2-1 B$, for fatty acid composition and produced an extraordinary oleic acid soybean genotype (Haun et al., 2014). Five research teams working on soybeans in 2015 effectively assessed the alteration efficacy 
of CRISPR/Cas9 tool in endogenous soybean gene in hairy roots, left a layout for using the Cas9 system to investigate soybean gene (Michno et al., 2015; Sun et al., 2015). Afterward, Du et al. (2016) associated the competence of TALENs and Cas9 in manipulating two genes, GmPDS11 and GmPDS18, in hairy roots of soybeans. Results exhibited that CRISPR/Cas9, particularly CRISPR/Cas9 with GmU6-16g-1 promoter, was much more effective than TALENs in simultaneous editing of two main alleles. In an experiment, homozygous mutants acquired by CRISPR/Cas9 facilitated mutation in the GmFT2a gene and delayed soybean flowering time (Cai et al., 2018). They altered GmFT5 by Cas9 method and crossed it with $\mathrm{ft} 2$ mutants, which had a flowering period 31 days later than the wild type, yielding more pods and ultimately higher yield (Cai et al., 2020). Likewise, the knockout of the GmSPL9 gene resulted in different mutants, which showed altered nod numbers and pod numbers (Bao et al., 2019). In addition, soybean seed oil quality (Al Amin et al., 2019), the beany taste of soybean seed (Wang et al., 2020a), and contents of isoflavone, as well as diseases resistance (Zhang et al., 2020), have been enhanced by CRISPR/Cas9 tool. The above research findings confirmed the great prospective of genome editing tools to back soybean enhancement. Many other novel genomic editing methods have been developed besides CRISPR/Cas9, such as CRISPR/Cas12a, base editing systems and other CRISPR/Cas alternatives.

Nonetheless, to our awareness, most of them have not yet been deployed in soybeans, excluding only one study that claims the use of Cas12a-RNP in protoplast of soybean to facilitate gene manipulation (Kim et al., 2017). Due to the unavailability of the latest stories on effective soybean redevelopment from protoplast, RNPbased genome alterations may not be a favored choice for future soybean research (Kim et al., 2017). The list of genes knockout by CRISPR/Cas9 is shown in Table 5. Therefore, CRISPR based genome editing could be potentially used in soybeans to develop high-yielding genotypes to ensure global food security. The use of this technique would lead to a green revolution in soybean yield and breeding and the products would be highly accepted in the society.

Table 5. List of different genes knockout by CRISPR/Cas9 in soybean

\begin{tabular}{|c|c|c|c|}
\hline Crop & Gene & Trait & References \\
\hline \multirow{13}{*}{ Soybean } & GmSPL9 & Plant stature & (Bao et al., 2019) \\
\hline & $G m F A D 2-1 B$ & Low linoleic acid & (Do et al., 2019) \\
\hline & $G m F T 2 a / 5 a$ & Early flowering & (Han et al., 2019) \\
\hline & $G m F 3 H 1$ & Hairy roots & (Zhang et al., 2020) \\
\hline & GmFT5a & Regional adoptability for high yield & (Cai et al., 2020) \\
\hline & GmPLAs & P efficiency & (Xiao et al., 2021) \\
\hline & GmAMS1 & Male sterile lines & (Chen et al., 2021) \\
\hline & $M S 1$ & Male fertility & (Fang et al., 2021) \\
\hline & GmFATB1 & Reduced saturated fatty acid & (Ma et al., 2021) \\
\hline & $G m K I X 8-1$ & Increase seed weight & (Nguyen et al., 2021) \\
\hline & $N B S-L R R$ & Disease's resistance & (Nagy et al., 2021) \\
\hline & GmJAGGED1 & Higher yield & (Cai et al., 2021) \\
\hline & e FAD2 & Fatty acids & (Xiao et al., 2022) \\
\hline
\end{tabular}

\section{Genome by sequencing (GBS) and its importance in soybean}

In the past times, soybean genome sequencing progress yielded numerous NGS-based condensed representation genotyping stages. These comprise condensed representation libraries, DNA sequencing, GBS, reduction of complication in polymorphic arrangement, reduction of the genome in restriction-site protection, and altered methods (Andrews et al., 2016). GBS is the most influential, modest, high-throughout, and profitable system for locating SNP markers (Happ et al., 2019). GBS is an improved RAD-seq system based on NGS and is a highly multiplexed and simple technique. 
Most recently, cost-effective use of GBS has made it more easy and feasible in soybeans compared with WGRS type method of soybean genotyping (Gutierrez-Gonzalez et al., 2019; Jiang et al., 2020). The GBSbased genotyping system has been regularly used in mapping genes and other molecular studies in soybeans. It has been validated as an effective system for high-resolution genetic diagraming and specific breeding practices in soybean crops (Getachew, 2019). Many different mapping populations have been sequenced using the GBS system, and various traits have been analyzed in soybeans. Moreover, GBS covers a much higher fraction of the genome than the SNP arrays currently available in soybean plants (Gorjanc et al., 2015). The SNP collections are characteristically established from a restricted sample of genotypes; however, GBS can predict genetic difference that is precise to a progeny. GBS system has the benefit that markers are developed using the progeny to be sequenced, thus reducing ascertainment prejudice. The flexibility, low price, and forecast precision of GBS make this a perfect method for GAB used in soybean at the present time. It would be increased soon because of its efficiency and low-cost nature.

\section{Use of genetic engineering techniques in soybean}

GE involves the manipulation of the host genome by any means, either natural or artificial (Shea et al., 2020). The most commonly used methods are Agrobacterium, particle bombardment, and protoplast transformation (National Research Council, 2004). The new genetic engineering technique is CRISPR/Cas9 (Editing, 2020). Genetic engineering works by introducing a gene of interest from one living organism to another. That gene expresses in the host organism and causes required changes (Shea et al., 2020). This technique is gaining a lot of attention due to its promising efficacy and effectiveness in improving agronomic traits of the crop (Arora and Narula, 2017; Wang et al., 2019). GE in soybeans was primarily completed in the late1990s (Aldemita and Hautea, 2018).

Meanwhile, this time, GE has been used regularly in soybeans. The GM soybean was planted on 90.7 million ha area in 2014 (Aldemita and Hautea, 2018). The main soybean which was developed was resistant to herbicides and called Roundup ready soybean (Shea et al., 2020). This soy cultivar permits farmers to use herbicides to destroy any weed in the field while not damaging the soybean (Shea et al., 2020). GE has been used to improve the protein quality of soybeans by changing biosynthetic response pathways (Falco et al., 1995; Liu, 2012). Moreover, GE has been used to change the contents of soybean oil by enhancing oleic acid contents, reducing linolenic acid contents, and slowing down the flowering duration in soybean (Cai et al., 2018). This can be completed via GE by knocking out specific genes accountable for the anti-nutritional factors. The transgene cultivars can raise public concerns about biosafety issues; however, different molecular techniques can be integrated to get more efficient cultivars (Alfonso, 2020).

\section{Conclusions}

We completed an organized review about soybean yield and quality improvement. Soybean yield and quality improvement have been attained by using conventional and molecular techniques. These factors have contributed to a comprehensive understanding of genetic factors for soybean yield and quality improvement. This compiled information could help to unfold the genetic architecture of soybean genetics and breeding. Being an important legume crop, efforts are still needed to conduct more novel research studies to enhance yield and quality. The studies should focus on the number of genes that play a key role in soybean domestication: yield, quality, and disease resistance. As the soybean crop faces numerous challenges, lack of fertile land, trade wars, lack of high-yielding cultivars, proper scientific research, there is a need to make a bright road map of proper scientific investigation for unfolding the genetic mechanism behind this. The detailed information presented in the current review gives a strong theoretical layout for future studies. As the use of 
the latest novel gene-editing techniques like CRISPR/Cas9 is increasing day by day, soybean yield and quality are the most significant traits to be improved currently. The gaps between the studies should be identified and addressed properly. This will likely be useful for achieving the maximum soybean yield from a given area.

High yield and quality of soybean attract the consumers and offers a huge benefit to the producer. The lack of genes is the main issue in using genetic management methods to develop yield and quality characters in soybean. As previous uses of breeding methods and genome editing in soybeans mostly concentrated on transforming a few recognized genes, most novel genomic resources are still unknown. Use of novel genome editing tools and breeding methods and can speed up the process of soybean development. Luckily, the joint use of genome editing methods and conventional methods would be more fruitful for maximizing yield and quality. In addition, a CRISPR-based mutant library can be used to develop novel traits in soybean (Rasheed et al., 2021a). It is difficult to make a genome-wide mutant library in soybeans, but it is possible to build a smallscale library for certain purposes. We strongly believe that CRISPR/Cas9 based targeted mutagenesis would develop novel soybean traits. Exploring wild soybean resources and their domestication by CRISPR could help us to understand soybean's genetic mechanism. CRISPR/Cas9 can mutate different recessive genes, and genetic diversity can be expanded to increase soybean yield and quality. Use of agronomic practices, like land management, use of growth hormones, irrigation, early planting of genotypes, and highly effective fertilizers could be more significant for yield and quality enhancement in soybean.

\section{Authors' Contributions}

GY supervised the study, AR prepared the draft, ZZ, JJG, MI, MA reviewed the manuscript. WP and SFAG provided technical assistance. MB improved scientific figures. WJ supervised the study.

All authors read and approved the final manuscript.

\section{Acknowledgements}

The authors are thankful to Dr. Wei JIAN for financial support for this study.

\section{Conflict of Interests}

The authors declare that there are no conflicts of interest related to this article.

\section{References}

Ahmar S, Gill RA, Jung KH, Faheem A, Qasim MU, Mubeen M, Zhou W (2020). Conventional and molecular techniques from simple breeding to speed breeding in crop plants: recent advances and future outlook. International Journal of Molecular Sciences 21:2590. https://doi.org/10.3390/ijms21072590

Al Amin N, Ahmad N, Wu N, Pu X, Ma T, Du Y, Bo X, Wang N, Sharif R, Wang (2019). CRISPR-Cas9 mediated targeted disruption of FAD2-2 microsomal omega-6 desaturase in soybean (Glycine max L.). BMC Biotechnology 19:1-10. https://doi.org/10.1186/s12896-019-0501-2

Alam T, Suryanto P, Handayani S, Kastono D, Kurniasih B (2020). Optimizing application of biochar, compost and nitrogen fertilizer in soybean intercropping with kayu putih (Melaleuca cajuputi). Revista Brasileira de Ciência do Solo 44:e0200003. https://doi.org/10.36783/18069657rbcs20200003

Aldemita RR, Hautea RA (2018). Biotech crop planting resumes high adoption in 2016. GM Crops and Food 9:1-12. https://doi.org/10.1080/21645698.2018.1428166 
Alfonso M (2020). Improving soybean seed oil without poor agronomics. Journal of Experimental Botany 71:6857-6860. https://doi.org/10.1093/jxb/eraa407

Amiri H, Ghalavand A, Mokhtassi-Bidgoli A (2021). Growth, seed yield and quality of soybean as affected by integrated fertilizer managements and zeolite application. Communications in Soil Science Plant Analysis 52:1834-1851. https://doi.org/10.1080/00103624.2021.1900222

Andrews KR, Good JM, Miller MR, Luikart G, Hohenlohe PA (2016). Harnessing the power of RADseq for ecological and evolutionary genomics. Nature Reviews Genetics 17:81-92. https://doi.org/10.1038/nrg.2015.28

Arora L, Narula A (2017). Gene editing and crop improvement using CRISPR-Cas9 system. Frontiers in Plant Science 8:1932. https://doi.org/10.3389/fpls.2017.01932

Ashraf M, Akram N, Arteca RN, Foolad MR (2010). The physiological, biochemical and molecular roles of brassinosteroids and salicylic acid in plant processes and salt tolerance. Critical Reviews in Plant Sciences 29:162190. https://doi.org/10.1080/07352689.2010.483580

Aytaç S, Çirak C, Özçelik H (2007). Foliar zinc application on yield and quality characters of soybean. Asian Journal of Chemistry 19(3):2410-2418.

Bai M, Yuan J, Kuang H, Gong P, Li S, Zhang Z, ... Yang L (2020). Generation of a multiplex mutagenesis population via pooled CRISPR-Cas9 in soya bean. Plant Biotechnology Journal 18:721-731. https://doi.org/10.1111/pbi.13239

Bao A, Chen H, Chen L, Chen S, Hao Q, Guo W, ... Yuan S (2019). CRISPR/Cas9-mediated targeted mutagenesis of GmSPL9 genes alters plant architecture in soybean. BMC Plant Biology 19:1-12. https://doi.org/10.1186/s12870-019-1746-6

Bhat JA, Ali S, Salgotra RK, Mir ZA, Dutta S, Jadon V, ... Singh PK (2016). Genomic selection in the era of next generation sequencing for complex traits in plant breeding. Frontiers in Genetics 7:221. https://doi.org/10.3389/fgene.2016.00221

Cai Y, Chen L, Liu X, Guo C, Sun S, Wu C, ... Hou W (2018). CRISPR/Cas9-mediated targeted mutagenesis of GmFT2a delays flowering time in soya bean. Plant Biotechnology Journal 16:176-185. https://doi.org/10.1111/pbi.12758

Cai Y, Wang L, Chen L, Wu T, Liu L, Sun S, ... Yuan S (2020). Mutagenesis of GmFT2a and GmFT5a mediated by CRISPR/Cas9 contributes for expanding the regional adaptability of soybean. Plant Biotechnology Journal 18:298-309. https://doi.org/10.1111/pbi.13199

Cai Z, Xian P, Cheng Y, Ma Q, Lian T, Nian H,Ge LJPBJ (2021). CRISPR/Cas9-mediated gene editing of GmJAGGED1 increased yield in the low-latitude soybean variety Huachun 6. Plant Biotechnology Journal 19(10):1898-1900. https://doi.org/10.1111/pbi.13673

Campbell BW, Hoyle JW, Bucciarelli B, Stec AO, Samac DA, Parrott WA, Stupar RMJGc (2019). Functional analysis and development of a CRISPR/Cas9 allelic series for a CPR5 ortholog necessary for proper growth of soybean trichomes. Scientific Reports 9:1-11. https://doi.org/10.1038/s41598-019-51240-7

Carter T, Hymowitz T, Nelson R (2004). Biogeography, local adaptation, Vavilov, and genetic diversity in soybean. In: Biological Resources and Migration. Springer, pp 47-59.

Chaudhary J, Patil GB, Sonah H, Deshmukh RK, Vuong TD, Valliyodan B, Nguyen HT (2015). Expanding omics resources for improvement of soybean seed composition traits. Frontiers in Plant Science 6:1021. https://doi.org/10.3389/fpls.2015.01021

Chen X, Yang S, Zhang Y, Zhu X, Yang X, Zhang C, Li H, Feng X (2021). Generation of male-sterile soybean lines with the CRISPR/Cas9 system. The Crop Journal 1-18. https://doi.org/10.1016/j.cj.2021.05.003

Cheng SH, Zhuang JY, Fan YY, Du JH, Cao LY (2007). Progress in research and development on hybrid rice: a superdomesticate in China. Annals of Botany 100:959-966. https://doi.org/10.1093/aob/mcm 121

Chiluwal A, Haramoto ER, Hildebrand D, Naeve S, Poffenbarger H, Purcell LC, Salmeron M (2021). Late-season nitrogen applications increase soybean yield and seed protein concentration. Frontiers in Plant Science 12:715940. https://doi.org/10.3389/fpls.2021.715940

Cober ER, Morrison MJ (2010). Regulation of seed yield and agronomic characters by photoperiod sensitivity and growth habit genes in soybean. Theoretical and Applied Genetics 120:1005-1012. http://dx.doi.org/10.1007/s00122009-1228-6

Cober ER, Voldeng HD (2008). Mass selection for small seed size in natto soybean populations and the resulting effect on seed yield. Crop Science 48:1337-1340. https://doi.org/10.2135/cropsci2007.07.0389

Contini E, Pena J, Vieira P (2013). Drought in the USA: agricultural prices and implications for Brazil. Revista de Politica Agricola 22:85-97. 
Curtin SJ, Zhang F, Sander JD, Haun WJ, Starker C, Baltes NJ, ... Coffman AP (2011). Targeted mutagenesis of duplicated genes in soybean with zinc-finger nucleases. Plant Physiology 156:466-473. https://doi.org/10.1104/pp.111.172981

Divito GA, Echeverría HE, Andrade FH, Sadras VO (2016). Soybean shows an attenuated nitrogen dilution curve irrespective of maturity group and sowing date. Field Crops Research 186:1-9. https://doi.org/10.1016/j.fcr.2015.11.004

Do PT, Nguyen CX, Bui HT, Tran LT, Stacey G, Gillman JD, ... Stacey MG (2019). Demonstration of highly efficient dual gRNA CRISPR/Cas9 editing of the homeologous GmFAD2-1A and GmFAD2-1B genes to yield a high oleic, low linoleic and $\alpha$-linolenic acid phenotype in soybean. BMC Plant Biology 19:1-14. https://doi.org/10.1186/s12870-019-1906-8

Dong Y, Zhao L, Liu B, Wang Z, Jin Z, Sun H (2004). The genetic diversity of cultivated soybean grown in China. Theoretical and Applied Genetics 108:931-936. https://doi.org/10.1007/s00122-003-1503-X

Du H, Zeng X, Zhao M, Cui X, Wang Q, Yang H, Cheng H, Yu D (2016). Efficient targeted mutagenesis in soybean by TALENs and CRISPR/Cas9. Journal of Biotechnology 217:90-97. https://doi.org/10.1016/j.jbiotec.2015.11.005

Duvick DN (2001). Biotechnology in the 1930s: the development of hybrid maize. Nature Reviews Genetics 2:69-74. https://doi.org/10.1038/35047587

Editing WAG (2020). CRISPR-Cas9. US National Library of Medicine: Genetics Home Reference.

Egli D, Cornelius P (2009). A regional analysis of the response of soybean yield to planting date. Agronomy Journal 101:330-335.

EL Toum GA, Khalifa NM,Ahmed AMS, Idris HAR (2020). Effect of planting date and sowing method on yield and grain quality of soybean (Glycine max L.) under North Sudan conditions. Moroccan Journal of Agricultural Sciences 1 .

Falco S, Guida T, Locke M, Mauvais J, Sanders C, Ward R, Webber P (1995). Transgenic canola and soybean seeds with increased lysine. Biotechnology 13:577-582. https://doi.org/10.1038/nbt0695-577

Fang X, Sun X, Yang X, Li Q, Lin C, Xu J, Gong W, Wang Y, Liu L, Zhao L (2021). MS1 is essential for male fertility by regulating the microsporocyte cell plate expansion in soybean. Science China Life Sciences 64:1533-1545. https://doi.org/10.1007/s11427-021-1973-0

Gai Z, Zhang J, Li C (2017). Effects of starter nitrogen fertilizer on soybean root activity, leaf photosynthesis and grain yield. PloS One 12:e0174841. https://doi.org/10.1371/journal.pone.0174841

Getachew T (2019). Pulse crops production opportunities, challenges and its value chain in Ethiopia: A review article. Journal of Environment Earth Science 9:20-29. https://doi.org/10.7176/JEES/9-1-03

Gizlice Z, Carter Jr TE, Gerig T, Burton J (1996). Genetic diversity patterns in North American public soybean cultivars based on coefficient of parentage. Crop Science 36:753-765. https://doi.org/10.2135/cropsci1996.0011183X003600030038x

Gorjanc G, Cleveland MA, Houston RD, Hickey JM (2015). Potential of genotyping-by-sequencing for genomic selection in livestock populations. Genetics Selection Evolution 47:1-14. https://doi.org/10.1186/s12711-015$0102-Z$

Guo J, Wang Y, Song C, Zhou J, Qiu L, Huang H, Wang Y (2010). A single origin and moderate bottleneck during domestication of soybean (Glycine max): implications from microsatellites and nucleotide sequences. Annals of Botany 106:505-514. https://doi.org/10.1093/aob/mcq125

Gupta PK, Balyan HS, Gahlaut V, Saripalli G, Pal B, Basnet BR, Joshi AK (2019). Hybrid wheat: past, present and future. Theoretical and Applied Genetics 132:2463-2483. https://doi.org/10.1007/s00122-019-03397-y

Gutierrez-Gonzalez JJ, Mascher M, Poland J, Muehlbauer GJ (2019). Dense genotyping-by-sequencing linkage maps of two synthetic W7984× Opata reference populations provide insights into wheat structural diversity. Scientific Reports 9:1-15. https://doi.org/10.1038/s41598-018-38111-3

Habier D, Fernando RL, Dekkers JC (2007). The impact of genetic relationship information on genome-assisted breeding values. Genetics 177:2389-2397. https://doi.org/10.1534/genetics.107.081190

Hacisalihoglu G, Burton AL, Gustin JL, Eker S, Asikli S, Heybet EH, Ozturk L, Cakmak I, Yazici A, Burkey KO (2018). Quantitative trait loci associated with soybean seed weight and composition under different phosphorus levels. Journal of Integrative Plant Biology 60:232-241. https://doi.org/10.1111/jipb.12612

Han J, Guo B, Guo Y, Zhang B, Wang X, Qiu LJ (2019). Creation of early flowering germplasm of soybean by CRISPR/Cas9 technology. Frontiers in Plant science 10:1446. https://doi.org/10.3389/fpls.2019.01446 
Han Y, Li D, Zhu D, Li H, Li X, Teng W, Li W (2012). QTL analysis of soybean seed weight across multi-genetic backgrounds and environments. Theoretical and Applied Genetics 125:671-683. https://doi.org/10.1007/s00122-012-1859-X

Happ MM, Wang H, Graef GL, Hyten DL (2019). Generating high-density, low-cost genotype data in soybean [ Glycine $\max ($ L.) Merr.]. G3: Genes, Genomes, Genetics 9:2153-2160. https://doi.org/10.1534/g3.119.400093

Hartung R, Specht J, Williams J (1981). Modification of soybean plant architecture by genes for stem growth habit and maturity 1. Crop Science 21:51-56. https://doi.org/10.2135/cropsci1981.0011183X002100010015x

Haun W, Coffman A, Clasen BM, Demorest ZL, Lowy A, Ray E, Retterath A, Stoddard T, Juillerat A, Cedrone F (2014). Improved soybean oil quality by targeted mutagenesis of the fatty acid desaturase 2 gene family. Plant Biotechnology Journal 12:934-940. https://doi.org/10.1111/pbi.12201

Hayat Q, Hayat S, Irfan M, Ahmad A (2010). Effect of exogenous salicylic acid under changing environment: a review. Environmental and Experimental Botany 68:14-25. https://doi.org/10.1016/j.envexpbot.2009.08.005

He R, Zhu D, Chen X, Cao Y, Chen Y, Wang X (2019). How the trade barrier changes environmental costs of agricultural production: An implication derived from China's demand for soybean caused by the US-China trade war. Journal of Cleaner Production 227:578-588. https://doi.org/10.1016/j.jclepro.2019.04.192

Hickey JM, Chiurugwi T, Mackay I, Powell W (2017). Genomic prediction unifies animal and plant breeding programs to form platforms for biological discovery. Nature Genetics 49:1297-1303. https://doi.org/10.1038/ng.3920

Hina A, Cao Y, Song S, Li S, Sharmin RA, Elattar MA, Bhat JA, Zhao T (2020). High-resolution mapping in two RIL populations refines major "QTL Hotspot" regions for seed size and shape in soybean (Glycine max L.). International Journal of Molecular Sciences 21:1040. https://doi.org/10.3390/ijms21031040

Ho P-T (1975). The cradle of the east: An inquiry into the indigenous origins of techniques and ideas of Neolitic and early historic China, 5000-1000 BC. Hong Kong: The Chinese University of Hong Kong, and Chicago: The University of Chicago Press, 1975.

Hua W, Luo P, An N, Cai F, Zhang S, Chen K, Yang J, Han X (2020). Manure application increased crop yields by promoting nitrogen use efficiency in the soils of 40-year soybean-maize rotation. Scientific Reports 10:1-10. https://doi.org/10.1038/s41598-020-71932-9

Huang W, Hou J, Hu Q, An J, Zhang Y, Han Q, ... Wang J (2021). Pedigree-based genetic dissection of quantitative loci for seed quality and yield characters in improved soybean. Molecular Breeding 41:1-15. https://doi.org/10.1007/s11032-021-01211-6

Hyten DL, Song Q, Zhu Y, Choi IY, Nelson RL, Costa JM, Specht JE, Shoemaker RC, Cregan PB (2006). Impacts of genetic bottlenecks on soybean genome diversity. Proceedings of the National Academy of Sciences 103:1666616671. https://doi.org/10.1073/pnas.0604379103

Jacobs TB, LaFayette PR, Schmitz RJ, Parrott W (2015). Targeted genome modifications in soybean with CRISPR/Cas9. BMC Biotechnology 15:1-10. https://doi.org/10.1186/s12896-015-0131-2

Jarecki W, Bobrecka-Jamro D (2021). Effect of sowing date on the yield and seed quality of Soybean [Glycine max (L.) Merr.]. Journal of Elementology 26:7-18.

Jiang B, Cheng Y, Cai Z, Li M, Jiang Z, Ma R, Yuan Y, Xia Q, Nian H (2020). Fine mapping of a Phytophthora-resistance locus RpsGZ in soybean using genotyping-by-sequencing. BMC Genomics 21:1-11. https://doi.org/10.1186/s12864-020-6668-Z

Kanazashi Y, Hirose A, Takahashi I, Mikami M, Endo M, Hirose S, Toki S, Kaga A, Naito K, Ishimoto M (2018). Simultaneous site-directed mutagenesis of duplicated loci in soybean using a single guide RNA. Plant Cell Reports 37:553-563. https://doi.org/10.1007/s00299-018-2251-3

Karikari B, Chen S, Xiao Y, Chang F, Zhou Y, Kong J, Bhat JA, Zhao TJE (2019). Utilization of interspecific high-density genetic map of RIL population for the QTL detection and candidate gene mining for 100-seed weight in soybean. Frontiers in Plant Science 10:1001. https://doi.org/10.3389/fpls.2019.01001

Kato S, Sayama T, Fujii K, Yumoto S, Kono Y, Hwang TY, Kikuchi A, Takada Y, Tanaka Y, Shiraiwa TJT (2014). A major and stable QTL associated with seed weight in soybean across multiple environments and genetic backgrounds. Theoretical Applied Genetics 127:1365-1374. https://doi.org/10.1007/s00122-014-2304-0

Kempster R, Barat M, Bishop L, Rufino M, Borras L, Dodd IC (2021). Genotype and cytokinin effects on soybean yield and biological nitrogen fixation across soil temperatures. Annals of Applied Biology 178:341-354. https://doi.org/10.1111/aab.12652 
Khan BA, Ali A, Nadeem MA, Elahi A, Adnan M, Amin MM, Ali MF, Waqas M, Aziz A, Sohail MK (2020). Impact of planting date and row spacing on growth, yield and quality of soybean: A Review. Journal of Biodiversity and Environmental Sciences 17:121-129.

Khan W, Prithiviraj B, Smith DL (2003). Photosynthetic responses of corn and soybean to foliar application of salicylates. Journal of Plant Physiology 160:485-492.

Kim H, Kim ST, Ryu J, Kang BC, Kim JS, Kim SG (2017). CRISPR/Cpf1-mediated DNA-free plant genome editing. Nature Communications 8:1-7. https://doi.org/10.1038/ncomms14406

Kim MY, Van K, Kang YJ, Kim KH, Lee SH (2012). Tracing soybean domestication history: From nucleotide to genome. Breeding Science 61:445-452. https://doi.org/10.1270/jsbbs.61.445

Klumpp G (2018). Effects of a plant growth regulator product on soybean at R2-R3. https://dr.lib.iastate.edu/handle/20.500.12876/17165

Lakpale R,Tripathi VK (2012). Broad-bed furrow and ridge and furrow method of sowing under different seed rates of soybean (Glycine max L.) for high rainfall areas of Chhattisgarh plains. Soybean Research 10:52-59.

Lee C, Choi MS, Kim HT, Yun HT, Lee B, Chung YS, Kim RW, Choi HK (2015). Soybean [Glycine max (L.) Merrill]: Importance as a crop and pedigree reconstruction of Korean varieties. Plant Breeding and Biotechnology 3:179196. https://doi.org/10.9787/PBB.2015.3.3.179

Lee GA, Crawford GW, Liu L, Sasaki Y, Chen X (2011). Archaeological soybean (Glycine max) in East Asia: does size matter? PloS One 6:e26720. https://doi.org/10.1371/journal.pone.0026720

Letham JL, Ketterings QM, Cherney JH, Overton TR (2021). Impact of sulfur application on soybean yield and quality in New York. Agronomy Journal 113:2851-2871. https://doi.org/10.1002/agj2.20690

Li D (2006). Soybean QTL for yield and yield components associated with Glycine soja alleles. University of Kentucky Doctoral Dissertations 331. https://uknowledge.uky.edu/gradschool_diss/331

Li F, Zhang X, Hu R, Wu F, Ma J, Meng Y, Fu Y (2013). Identification and molecular characterization of FKF1 and GI homologous genes in soybean. PLoS One 8:e79036. https://doi.org/10.1371/journal.pone.0079036

Li R, Jiang H, Zhang Z, Zhao Y, Xie J, Wang Q, ... Xin D (2020). Combined linkage mapping and BSA to identify QTL and candidate genes for plant height and the number of nodes on the main stem in soybean. International Journal of Molecular Sciences 21:42. https://doi.org/10.3390/ijms21010042

Li YH, Li W, Zhang C, Yang L, Chang RZ, Gaut BS, Qiu LJ (2010). Genetic diversity in domesticated soybean (Glycine $\max$ ) and its wild progenitor (Glycine soja) for simple sequence repeat and single-nucleotide polymorphism loci. New Phytologist 188:242-253. https://doi.org/10.1111/j.1469-8137.2010.03344.X

Liang HZ, Yu YL, Wang SF, Yun L, Wang TF, Wei YL, Gong PT, Liu XY, Fang XJ, Zhang MC (2010). QTL mapping of isoflavone, oil and protein contents in soybean (Glycine max L. Merr.). Agricultural Sciences in China 9:11081116. https://doi.org/10.1016/S1671-2927(09)60197-8

Liu D, Yan Y, Fujita Y, Xu DJBs (2018). Identification and validation of QTLs for 100-seed weight using chromosome segment substitution lines in soybean. Breeding Science 68:442-448. https://doi.org/10.1270/jsbbs.17127

Liu J, Li M, Zhang Q, Wei X, Huang X (2020a). Exploring the molecular basis of heterosis for plant breeding. Journal of Integrative Plant Biology 62:287-298. https://doi.org/10.1111/jipb.12804

Liu K (2012). Soybeans: chemistry, technology, and utilization. Springer.

Liu N, Li M, Hu X, Ma Q, Mu Y, Tan Z, Xia Q, Zhang G, Nian H (2017a). Construction of high-density genetic map and QTL mapping of yield-related and two quality traits in soybean RILs population by RAD-sequencing. BMC Genomics18:1-13. https://doi.org/10.1186/s12864-017-3854-8

Liu S, Zhang M, Feng F, Tian Z (2020b). Toward a "green revolution" for soybean. Molecular Plant 13:688-697. https://doi.org/10.1016/j.molp.2020.03.002

Liu Z, Li H, Wen Z, Fan X, Li Y, Guan R, Guo Y, Wang S, Wang D, Qiu L (2017b). Comparison of genetic diversity between Chinese and American soybean (Glycine max (L.)) accessions revealed by high-density SNPs. Frontiers in Plant Science 8:2014. https://doi.org/10.3389/fpls.2017.02014

Llanes A, Iparraguirre J, Masciarelli O, Maria N, Luna MV (2019). Foliar application of phytohormones enhances growth of maize and soybean seedlings. Rep. No. 0325-8718, Ediciones INTA.

Lueschen W, Ford J, Evans S, Kanne B, Hoverstad T, Randall G, Orf J, Hicks D (1992). Tillage, row spacing, and planting date effects on soybean following corn or wheat. Journal of Production Agriculture 5:254-260. https://doi.org/10.2134/jpa1992.0254 
Ma J, Sun S, Whelan J, Shou H (2021). CRISPR/Cas9-Mediated knockout of GmFATB1 significantly reduced the amount of saturated fatty acids in soybean seeds. International Journal of Molecular Sciences 22:3877. https://doi.org/10.3390/ijms22083877

Ma Y, Kan G, Zhang X, Wang Y, Zhang W, Du H, Yu D (2016). Quantitative trait loci (QTL) mapping for glycinin and $\beta$-conglycinin contents in soybean (Glycine max L. Merr.). Journal of Agricultural Food Chemistry 64:3473-3483. https://doi.org/10.1021/acs.jafc.6b00167

Michno JM, Wang X, Liu J, Curtin SJ, Kono TJ, Stupar RM (2015). CRISPR/Cas mutagenesis of soybean and Medicago truncatula using a new web-tool and a modified Cas9 enzyme. GM Crops 6:243-252. https://doi.org/10.1080/21645698.2015.1106063

Mir RR, Reynolds M, Pinto F, Khan MA, Bhat MA (2019). High-throughput phenotyping for crop improvement in the genomics era. Plant Scienc 282:60-72. https://doi.org/10.1016/j.plantsci.2019.01.007

Nagy ED, Stevens JL, Yu N, Hubmeier CS, LaFaver N, Gillespie M, Gardunia B, Cheng Q, Johnson S, Vaughn A (2021). Novel disease resistance gene paralogs created by CRISPR/Cas9 in soy. Plant Cell Reports 40:1047-1058. https://doi.org/10.1007/s00299-021-02678-5

National Research Council (2004). National Research Council (US) Committee on Identifying and Assessing Unintended Effects of Genetically Engineered Foods on Human Health. Safety of Genetically Engineered Foods: Approaches to Assessing Unintended Health Effects. Washington (DC): National Academies Press (US), PMID: 25009871.

Nguyen CX, Paddock KJ, Zhang Z, Stacey MG (2021). GmKIX8-1 regulates organ size in soybean and is the causative gene for the major seed weight QTL qSw17-1. New Phytologist 229:920-934. https://doi.org/10.1111/nph.16928

Nico M, Miralles DJ, Kantolic AG (2019). Natural post-flowering photoperiod and photoperiod sensitivity: Roles in yield-determining processes in soybean. Field Crops Research 231:141-152. https://doi.org/10.1016/j.fcr.2018.10.019

Nonokawa K, Kokubun M, Nakajima T, Nakamura T, Yoshida R (2007). Roles of auxin and cytokinin in soybean pod setting. Plant Production Science 10:199-206. https://doi.org/10.1626/pps.10.199

Obata H, Manabe A (2011). Issues on the early agriculture in Korea and Japan, based on recent archaeobotanical studies. In: Current research on the Neolithic period in Japan and Korea: Proceedings of the 9th conference of the Kyushu Jomon Kenkyukai and the Korean Neolithic Research Society. Iki: Kyushu Jomon Kenkyukai, pp 1-30.

Ohyama T, Tewari K, Ishikawa S, Tanaka K, Kamiyama S, Ono Y, Hatano S, Ohtake N, Sueyosh K, Hasegawa H (2017). Role of nitrogen on growth and seed yield of soybean and a new fertilization technique to promote nitrogen fixation and seed yield. In: Kasai NM (Ed). Soybean: The Basis of Yield, Biomass and Productivity, pp 153-18. https://doi.org/doi:10.5772/66743

Onyenali T, Olowe V, Fabunmi T, Soretire A (2020). Organic fertilizers improve the growth, seed quality and yield of newly released soybean (Glycine $\max$ (L.) Merrill) varieties in the tropics. Organic Agriculture 10:155-170. https://doi.org/10.1007/s13165-019-00258-2

Palmer R, Gai J, Sun H, Burton J (2001). Production and evaluation of hybrid soybean. Plant Breeding Reviews 21:263307.

Panthee D, Pantalone V, Saxton A, West D, Sams C (2007). Quantitative trait loci for agronomic traits in soybean. Plant Breeding 126:51-57. https://doi.org/10.1111/j.1439-0523.2006.01305.x

Prince SJ, Vuong TD, Wu X, Bai Y, Lu F, Kumpatla SP, Valliyodan B, Shannon JG, Nguyen HT (2020). Mapping quantitative trait loci for soybean seedling shoot and root architecture traits in an inter-specific genetic population. Frontiers in Plant Science 11:1284. https://doi.org/10.3389/fpls.2020.01284

Qi Z, Song J, Zhang K, Liu S, Tian X, Wang Y, Fang Y, Li X, Wang J, Yang C (2020). Identification of QTNs controlling 100-seed weight in soybean using multilocus genome-wide association studies. Frontiers in Genetics 11:689. https://doi.org/10.3389/fgene.2020.00689

Rasheed A, Ahmed S, Wassan GM, Solangi AM, Aamer M, Khanzada H, Keerio AA, Qadeer A, Israr A (2018). Estimation of hybrid vigor for yield and yield related traits in tomato (Solanum lycopersicon Mill). International Journal of Bioscience 12(1):160-167. http://dx.doi.org/10.12692/ijb/12.1.160-167

Rasheed A, Ilyas M, Khan TN, Nawab NN, Ahmed I, Hussain MM, Khan AA, Kabir N, Intikhab A (2017). Genetic association and path coefficient analysis among yield and yield related traits in tomato (Solanum lycopersicon Mill.). International Journal of Biosciences 11(5):21-26. https://doi.org/10.12692/ijb/11.5.21-26. 
Rasheed A, Tahir MM, Ilyas M (2019). An investigation on genetic variability for different quantitative and qualitative traits of wheat (Triticum aestivum L) genotypes. Gomal University Journal of Research 35(1):67-74.

Rasheed A, Fahad S, Hassan MU, Tahir MM, Aamer M, Wu Z (2020a). A review on aluminum toxicity and quantitative trait loci maping in rice (Oryza sativa L). Applied Ecology and Environmental Research 18:3951-3961. http://dx.doi.org/10.15666/aeer/1803_39513964

Rasheed A, Fahad S, Amer M, Hassan MU, Tahir MM, Wu Z (2020b). Role of genetic factors in regulating cadmium uptake, transport and accumulation mechanisms and quantitative trait loci mapping in rice. a review. Applied Ecology and Environmental Research 18:4005-4023. http://dx.doi.org/10.15666/aeer/1803_40054023

Rasheed A, Gill RA, Hassan MU, Mahmood A, Qari S, Zaman QU, ... Wu Z (2021a). A critical review: recent advancements in the use of CRISPR/Cas9 technology to enhance crops and alleviate global food crises. Current Issues in Molecular Biology 43:1950-1976. https://doi.org/10.3390/cimb43030135

Rasheed A, Hassan M, Aamer M, Bian J, Xu Z, He X,Wu Z (2020). Iron toxicity, tolerance and quantitative trait loci mapping in rice: a review. Applied Ecology and Environmental Research 18:7483-7498. http://dx.doi.org/10.15666/aeer/1806_74837498

Rasheed A, Hassan MU, Fahad S, Aamer M, Batool M, Ilyas M, Shang F, Wu Z, Li H (2021b). Heavy metals stress and plants defense responses. In: Sustainable Soil and Land Management and Climate Change. CRC Press, pp 57-82.

Rasheed A, Wassan GM, Khanzada H, Solangi AM, Han R, Li H, Bian J, Wu Z (2021c). Identification of genomic regions at seedling related traits in response to aluminium toxicity using a new high-density genetic map in rice (Oryza sativa L.). Genetic Resources and Crop Evolution 68:1889-1903. https://doi.org/10.1007/s10722-020-01103-2

Rincker K, Nelson R, Specht J, Sleper D, Cary T, Cianzio SR, Casteel S, Conley S, Chen P, Davis V (2014). Genetic improvement of US soybean in maturity groups II, III, and IV. Crop Breeding and Genetics 54:1419-1432. https://doi.org/10.2135/cropsci2013.10.0665

Robinson AP, Conley SP, Volenec JJ, Santini JB (2009). Analysis of high yielding, early-planted soybean in Indiana. Agronomy Journal 101:131-139.

Santner A, Estelle M (2009). Recent advances and emerging trends in plant hormone signalling. Nature 459:1071-1078. https://doi.org/10.1038/nature08122

Santos LO, Moraes LAC, Petineli R, Moretti LG, Moreira A (2020). Yield, yield components, soil fertility, and nutritional status of soybean as influenced by limestone and copper interactions. Journal of Plant Nutrition 43:2445-2454. https://doi.org/10.1080/01904167.2020.1783308

Seiler GJ,Qi LL,Marek LF (2017). Utilization of sunflower crop wild relatives for cultivated sunflower improvement. Crop Science 57:1083-1101. https://doi.org/10.2135/cropsci2016.10.0856

Shahkoomahally E, Shahkoomahally S (2017). Investigating of N and K Fertilizers on yield and components of soybean (Glycine max (L.). Journal of Agricultural Science 9:85. https://doi.org/10.5539/jas.v9n10p85

Sharmin RA, Bhuiyan MR, Lv W,Yu Z, Chang F, Kong J, Bhat JA, Zhao T (2020). RNA-Seq based transcriptomic analysis revealed genes associated with seed-flooding tolerance in wild soybean (Glycine soja Sieb. \& Zucc.). Environmental Experimental Botany 171:103906. https://doi.org/10.1016/j.envexpbot.2019.103906

Shea Z, Singer WM, Zhang B (2020). Soybean production, versatility, and improvement. In: Legume Crops-Prospects, Production and Uses. IntechOpen.

Silva LCC, da Matta LB, Pereira GR, Bueno RD, Piovesan ND, Cardinal AJ, God PIVG, Ribeiro C, Dal-Bianco M (2021). Association studies and QTL mapping for soybean oil content and composition. Euphytica 217:1-18. https://doi.org/10.1007/s10681-020-02755-y

Solanke A, Pawar G, Dhage R, Kamble B (2018). Effect of plant growth regulators on growth and yield of soybean ( $G l y c i n e$ max L.) applied at different stages. International Journal of Chemical Studies 6:2962-2966.

Steiner B, Michel S, Maccaferri M, Lemmens M, Tuberosa R, Buerstmayr H (2019). Exploring and exploiting the genetic variation of Fusarium head blight resistance for genomic-assisted breeding in the elite durum wheat gene pool. Theoretical and Applied Genetics 132:969-988. https://doi.org/10.1007/s00122-018-3253-9

Su D, Jiang S, Wang J, Yang C, Li W,Li WX, Ning HJB, Equipment B (2019). Identification of major QTLs associated with agronomical traits and candidate gene mining in soybean. Biotechnology and Biotechnological Equipment 33:1481-1493. https://doi.org/10.1080/13102818.2019.1674691

Sun X, Hu Z, Chen R, Jiang Q, Song G, Zhang H, Xi Y (2015). Targeted mutagenesis in soybean using the CRISPR-Cas9 system. Scientific Reports 5:1-10. https://doi.org/10.1038/srep10342

Taniguchi T, Murayama N, Hasegawa M, Nakagawa A, Tanaka S, Zheng SH, Hamaoka N, Iwaya-Inoue M, Ishibashi Y (2018). Vegetative growth after flowering through gibberellin biosynthesis regulates pod setting rate in soybean 
Yuhong G et al. (2021). Not Bot Horti Agrobo 49(4):12555

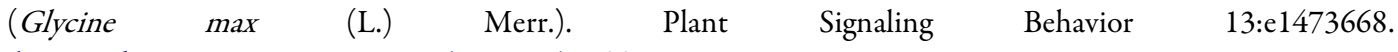
https://doi.org/10.1080/15592324.2018.1473668

Togashi A, Oikawa S (2021). Leaf productivity and persistence have been improved during soybean (Glycine max) domestication and evolution. Journal of Plant Research 134:223-233. https://doi.org/10.1007/s10265-02101263-X

Travaglia C, Reinoso H, Bottini R (2009). Application of abscisic acid promotes yield in field-cultured soybean by enhancing production of carbohydrates and their allocation in seed. Crop Pasture Science 60:1131-1136. https://doi.org/10.1071/CP08396

Van K, McHale LK (2017). Meta-analyses of QTLs associated with protein and oil contents and compositions in soybean

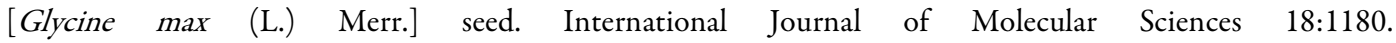
https://doi.org/10.3390/ijms18061180

Wang J, Kuang H, Zhang Z, Yang Y, Yan L, Zhang M, Song S, Guan Y (2020a). Generation of seed lipoxygenase-free soybean using CRISPR-Cas9. The Crop Journal 8:432-439. https://doi.org/10.1016/j.cj.2019.08.008

Wang L, Wang L, Guo Q (2007). Soybean cultivar improvement and innovation. Contemporary Soybean Research in China. Jindun Press, Beijing 281-282.

Wang T, Zhang H, Zhu H (2019). CRISPR technology is revolutionizing the improvement of tomato and other fruit crops. Horticulture Research 6:1-13. https://doi.org/10.1038/s41438-019-0159-x

Wang X, Jiang GL, Green M, Scott RA, Song Q, Hyten DL, Cregan PB (2014). Identification and validation of quantitative trait loci for seed yield, oil and protein contents in two recombinant inbred line populations of soybean. Molecular genetics genomics 289:935-949. https://doi.org/10.1007/s00438-014-0865-X

Wang Z, Bao G, Yang C, Yang M, Zhao X, Shao Y, Wang Y, Huang J, Xia N, Han Y (2020b). A genome-wide association study of hexanal content related to soymilk off-flavours in seed of soybean (Glycine max). Crop and Pasture Science 71:552-561. https://doi.org/10.1071/CP20068

Wu D, Zhan Y, Sun Q, Xu L, Lian M, Zhao X, Han Y, Li W (2018). Identification of quantitative trait loci underlying soybean (Glycine max [L.] Merr.) seed weight including main, epistatic and QTLx environment effects in different regions of Northeast China. Plant Breeding 137:194-202. https://doi.org/10.1111/pbr.12574

Xia N, Yang M, Zhao J, Shao Y, Shi Y, Yan W, Wang X, Han Y, Wang Z (2019). Genome-wide association analysis of 1octen-3-ol content related to soymilk off-flavor in soybean seed. Crop and Pasture Science 70:133-139. https://doi.org/10.1071/CP18423

Xiao Y, Karikari B, Wang L, Chang F, Zhao T (2021). Structure characterization and potential role of soybean phospholipases A multigene family in response to multiple abiotic stress uncovered by CRISPR/Cas9 technology. Environmental and Experimental Botany 188:104521. https://doi.org/10.1016/j.envexpbot.2021.104521

Xiao Z, Jin Y, Zhang Q, Lamboro A, Dong B, Yang Z, Wang P (2022). Construction and Functional Analysis of CRISPR/Cas9 Vector of FAD2 Gene Family in Soybean. Phyton 91:349. https://doi.org/10.32604/phyton.2022.017451

Xue H, Tian X, Zhang K, Li W, Qi Z, Fang Y, Li X, Wang Y, Song J, Li WX (2019). Mapping developmental QTL for plant height in soybean [Glycine $\max (\mathrm{L}$.$) using a four-way recombinant inbred line population. PloS One$ 14:e0224897. https://doi.org/10.1371/journal.pone.0224897

Yan L, Li YH, Yang CY, Ren SX, Chang RZ, Zhang MC, Qiu LJ (2014). Identification and validation of an overdominant QTL controlling soybean seed weight using populations derived from Glycine max $\times$ Glycine soja. Plant Breeding 133:632-637. https://doi.org/10.1111/pbr.12197

Yao J, Zhao D, Chen X, Zhang Y, Wang J (2018). Use of genomic selection and breeding simulation in cross prediction for improvement of yield and quality in wheat (Triticum aestivum L.). The Crop Journal 6:353-365. https://doi.org/10.1016/j.cj.2018.05.003

Yi J, Derynck MR, Chen L, Dhaubhadel S (2010). Differential expression of CHS7 and CHS8 genes in soybean. Planta 231:741-53. https://doi.org/10.1007/s00425-009-1079-Z

Yue Y, Liu N, Jiang B, Li M, Wang H, Jiang Z, Pan H, Xia Q, Ma Q, Han T (2017). A single nucleotide deletion in J encoding GmELF3 confers long juvenility and is associated with adaption of tropic soybean. Molecular Plant 10:656-658. https://doi.org/10.1016/j.molp.2016.12.004

Zhang D, Cheng H, Wang H, Zhang H, Liu C, Yu D, Genomics (2010a). Identification of genomic regions determining flower and pod numbers development in soybean (Glycine max L.). Journal of Genetics 37:545-556. https://doi.org/10.1016/S1673-8527(09)60074-6 
Zhang D, Zhang H, Hu Z, Chu S, Yu K, Lv L, Yang Y, Zhang X, Chen X, Kan G (2019). Artificial selection on GmOLEO1 contributes to the increase in seed oil during soybean domestication. PLoS Genetics 15:e1008267. https://doi.org/10.1371/journal.pgen.1008267

Zhang J, Wang X, Lu Y, Bhusal SJ, Song Q, Cregan PB, Yen Y, Brown M, Jiang GL (2018). Genome-wide scan for seed composition provides insights into soybean quality improvement and the impacts of domestication and breeding. Molecular Plant 11:460-472. https://doi.org/10.1016/j.molp.2017.12.016

Zhang P, Du H, Wang J, Pu Y, Yang C, Yan R, Yang H, Cheng H, Yu D (2020). Multiplex CRISPR/Cas9-mediated metabolic engineering increases soya bean isoflavone content and resistance to soya bean mosaic virus. Plant Biotechnology Journal 18:1384-1395. https://doi.org/10.1111/pbi.13302

Zhang Y, Gao Ql, Herbert S, Li YS, Hashemi A (2010b). Influence of sowing date on phenological stages, seed growth and marketable yield of four vegetable soybean cultivars in North-eastern USA. African Journal of Agricultural 5:2556-2562.

Zhang S, Hao D, Zhang S, Zhang D, Wang H, Du H, Kan G, Yu D (2021). Genome-wide association mapping for protein, oil and water-soluble protein contents in soybean. Molecular Genetics and Genomics 296:91-102. https://doi.org/10.1007/s00438-020-01704-7

Zhao Q, Shi X, Yan L, Yang C, Liu C, Feng Y, Zhang M, Yang Y, Liao H (2021). Characterization of the common genetic basis underlying seed hilum size, yield, and quality traits in soybean. Frontiers in Plant Science 12:183. https://doi.org/10.3389/fpls.2021.610214

Zheng N, Li T, Dittman JD, Su J, Li R, Gassmann W, Peng D, Whitham SA, Liu S, Yang B (2020). CRISPR/Cas9-based gene editing using egg cell-specific promoters in Arabidopsis and soybean. Frontiers in Plant Science 11:800. https://doi.org/10.3389/fpls.2020.00800

Zheng YZ, Gai JY, Lu WG, Li WD, Zhou RB, Tian SJ (2006). QTL mapping for fat and fatty acid composition contents in soybean. Acta Agronomica Sinica 32:1823-1830.

Zhijun Z (2004). Floatation: A paleobotanic method in field archaeology. Archeology 3:80-87.

Zhou H, Liu B, Weeks DP, Spalding MH, Yang B (2014). Large chromosomal deletions and heritable small genetic changes induced by CRISPR/Cas9 in rice. Nucleic Acids Research 42:10903-10914. https://doi.org/10.1093/nar/gku806

Zhou X, Carter TE, Cui Z, Miyazaki S, Burton JW (2000). Genetic base of Japanese soybean cultivars released during 1950 to 1988. Crop Science 40:1794-1802. https://doi.org/10.2135/cropsci2000.4061794x

Zhou Z, Jiang Y, Wang Z, Gou Z, Lyu J, Li W, Yu Y, Shu L, Zhao Y, Ma Y (2015). Resequencing 302 wild and cultivated accessions identifies genes related to domestication and improvement in soybean. Nature Biotechnology 33:408414. https://doi.org/10.1038/nbt.3096

Zhu X, Leiser WL, Hahn V, Würschum T (2021). Identification of QTL for seed yield and agronomic traits in 944 soybean (Glycine max) RILs from a diallel cross of early-maturing varieties. Plant Breeding 140:254-266. https://doi.org/10.1111/pbr.12900
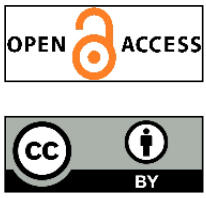

The journal offers free, immediate, and unrestricted access to peer-reviewed research and scholarly work. Users are allowed to read, download, copy, distribute, print, search, or link to the full texts of the articles, or use them for any other lawful purpose, without asking prior permission from the publisher or the author.

License - Articles published in Notulae Botanicae Horti Agrobotanici Cluj-Napoca are Open-Access, distributed under the terms and conditions of the Creative Commons Attribution (CC BY 4.0) License.

(c) Articles by the authors; UASVM, Cluj-Napoca, Romania. The journal allows the author(s) to hold the copyright/to retain publishing rights without restriction. 